\title{
Stress and Hemostasis: An Update
}

\author{
Anthony W. Austin, $\mathrm{PhD}^{1,2,3}$ Thomas Wissmann, $\mathrm{BSC}^{4}$ Roland von Kanel, MD $\mathrm{MD}^{4,5,6}$
}

${ }^{1}$ Montreal Behavioural Medicine Centre, Hôpital du Sacré-Cœur de Montréal, Montréal, Quebec, Canada

2 Department of Exercise Science, Concordia University, Montréal, Quebec, Canada

3 Research Centre, Hôpital du Sacré-Cœur de Montréal, Montréal, Quebec, Canada

${ }^{4}$ Division of Psychosomatic Medicine, Department of General Internal Medicine, Inselspital, Bern University Hospital and University of Bern, Bern, Switzerland

${ }^{5}$ Department of Clinical Research, University of Bern, Bern, Switzerland

6 Psychocardiology Unit, Cardiovascular Prevention and Rehabilitation, Swiss Cardiovascular Center, Inselspital, Bern University Hospital and University of Bern, Bern, Switzerland
Address for correspondence Roland von Kanel, MD, Department of General Internal Medicine, Inselspital, Bern University Hospital, $\mathrm{CH}$ 3010 Bern, Switzerland (e-mail: roland.vonkaenel@insel.ch).

Semin Thromb Hemost 2013;39:902-912.

\begin{abstract}
Numerous naturalistic, experimental, and mechanistic studies strongly support the notion that-as part of fight-or-flight response-hemostatic responses to acute psychosocial stress result in net hypercoagulability, which would protect a healthy organism from bleeding in case of injury. Sociodemographic factors, mental states, and comorbidities are important modulators of the acute prothrombotic stress response. In patients with atherosclerosis, exaggerated and prolonged stress-hypercoagulability might accelerate coronary thrombus growth following plaque rupture. Against a background risk from acquired prothrombotic conditions and inherited thrombophilia, acute stress also might trigger venous thromboembolic events. Chronic stressors such as job strain, dementia caregiving, and posttraumatic stress disorder as well as psychological distress from depressive and anxiety symptoms elicit a chronic low-grade hypercoagulable state that is no longer viewed as physiological but might impair vascular health. Through activation of the sympathetic nervous system, higher order cognitive processes and corticolimbic brain areas shape the acute prothrombotic stress response. Hypothalamic-pituitary-adrenal axis and autonomic dysfunction, including vagal withdrawal,

Keywords

- blood coagulation

- fibrinolysis

- platelets

- psychological stress

- risk factor are important regulators of hemostatic activity with longer lasting stress. Randomized placebo-controlled trials suggest that several cardiovascular drugs attenuate the acute prothrombotic stress response. Behavioral interventions and psychotropic medications might mitigate chronic low-grade hypercoagulability in stressed individuals, but further studies are clearly needed. Restoring normal hemostatic function with biobehavioral interventions bears the potential to ultimately decrease the risk of thrombotic diseases.
\end{abstract}

Dr. Samuel Silverman, 62, is one psychoanalyst willing to declare that Richard Nixon's phlebitis is psychosomatic. The man has been under extraordinary pressure for more than a year, Dr. Silverman says. Mr. Nixon seems to keep his emotions under such control that we might have expected physical instead of emotional breakdown.

Time Magazine, September 30, 1974, p. 65.
This introductory "case vignette" raises the question of whether intense emotional stress, such as experienced by the United States President Nixon in the wake of the Watergate scandal, is capable of causing thrombosisassociated diseases and, if so, by which mechanisms. Thus, the aim of this review is to provide an update on the sizeable literature on stress-related changes in the published online October 10, 2013
Issue Theme Coagulation and the Brain; Guest Editors, Benjamin Brenner, MD, and Jean-Christophe Gris, MD, PhD.
Copyright $\odot 2013$ by Thieme Medical Publishers, Inc., 333 Seventh Avenue, New York, NY 10001, USA. Tel: +1(212) 584-4662.
DOI http://dx.doi.org/ 10.1055/s-0033-1357487. ISSN 0094-6176. 
hemostatic system (i.e., coagulation, fibrinolysis, and platelets) and their potential role in thrombosis. As a prerequisite for the notion that stress-associated hypercoagulability contributes to thrombotic events, ${ }^{1}$ abundant epidemiological and experimental data exist supporting the role of enhanced coagulation, impaired fibrinolysis, and hyperactive platelets in the development of atherogenesis, atherothrombosis, and acute coronary syndromes (ACSs). ${ }^{2}$ Also, against a background risk from acquired prothrombotic conditions (e.g., varicosis, immobility) and inherited thrombophilia, even "trivial" triggers such as stress, might bring forward a prothrombotic state that results in onset of venous thromboembolism (VTE). ${ }^{3}$

After introducing the evolutionary meaning versus potential harm for the vasculature of a prothrombotic stress response, we present epidemiological and observational data on the role of stress in atherothrombotic diseases and VTE. We then depict the most salient mechanisms that may link psychosocial stress with hemostatic alterations, including the role of the brain and important health characteristics. Finally, we summarize findings from randomized, placebo-controlled drug trials, and behavioral interventions targeting stress-related hemostatic changes.

\section{Evolutionary Benefit versus Health Risk}

First, we should highlight an important distinction between the vascular consequences of acute versus chronic stress effects on hemostasis. In the case of acute stress, a prothrombotic state is clearly viewed as an adaptive physiological response to prevent a healthy organism in fight-or-flight situations from potentially excessive bleeding in case of injury. ${ }^{4}$ However, due to a dysfunctional endothelium having lost its anticoagulant properties (e.g., reduced release of nitric oxide and tissue-type plasminogen activator $[\mathrm{t}-\mathrm{PA}])^{5}{ }^{5}$ the prothrombotic stress response may be excessive in patients with cardiovascular disease (CVD), which may increase the risk of stress-triggered atherothrombotic events. ${ }^{1}$ For instance, if tested 1 year after having survived an ACS, patients who reported emotional triggering showed significantly greater increases and longer recovery of platelet-leukocyte aggregates after acute psychosocial stress than the nontriggering group. ${ }^{6}$ In the case of chronic stress, sustained low-grade hypercoagulability does not seem to be of evolutionary benefit in healthy individuals and might be harmful to the cardiovascular system in the long run, contributing to atherosclerosis progression. ${ }^{4,5,7}$ Such harm might pose greater risk in those with comorbid conditions and thrombotic risk factors. Therefore, individuals with the largest prothrombotic responses to stress and the greatest stress exposure in everyday life would be predicted to be at greater risk for thrombotic diseases. ${ }^{8}$

\section{Stress and Thrombotic Disorders}

Meta-analyses from the past decade strongly suggest that psychosocial stress contributes to morbidity and mortality from atherothrombotic CVD with a 1.5- to 2.5-fold excess risk. ${ }^{8,9}$
In the worldwide INTERHEART case-control study, one-third of the population attributable risk of myocardial infarction (MI) could be assigned to psychosocial factors, including major life events, lack of control, depression, work stress, family stress, and financial stress. ${ }^{10}$ The effect size of MI risk explained by psychosocial stress in INTERHEART was similar to that explained by traditional CVD risk factors.

Similarly, evidence from prospective studies suggests that psychosocial factors are predictive of VTE. Persistently perceived stress and low socioeconomic status (SES) increase the risk of VTE independent of demographics, lifestyle, and CVD risk factors. ${ }^{11,12}$ Depressed subjects from a population-based study had a 1.6-fold higher risk of incident VTE over a median follow-up of 12 years compared with those not depressed, controlling for other risk factors. ${ }^{13}$ Conversely, those who often felt happy or optimistic had a reduced risk of VTE. ${ }^{13}$ Acute traumatic stress arising after natural disasters has been implicated as a potential triggering factor of pulmonary embolism. ${ }^{14}$ Moreover, the mental stress from fear of flying with the accompanying coagulation activation may contribute to VTE during long-haul air travel. ${ }^{15}$

Several mechanisms are suggested to link stress to increased risk of atherothrombotic events ${ }^{6,7}$ and similar factors may play a role in VTE. ${ }^{16}$ Stress particularly promotes adverse health behaviors and initiates autonomic and neuroendocrine changes, all bringing forth physiological perturbations (e.g., hypercoagulability) which are potentially harmful to the vasculature. ${ }^{1,4,5,7,17-19}$ We will now discuss mechanisms possibly contributing to acute and chronic hemostatic changes as part of the human stress response, including brain processing of stressful stimuli and autonomic and neuroendocrine functioning.

\section{Psychosocial Stress, the Brain, and the Prothrombotic State}

"Stress" is an ambiguous term embedding different processes, namely, a stimulus (i.e., the "stressor" in the form of environmental challenges), perceptual processing of this input (i.e., perceived "distress" with the accompanying negative effects), and behavioral and physiological output (i.e., the "stress response"). ${ }^{20}$ This cascade of events helps explain why not only demanding life circumstances (e.g., providing care to a spouse with dementia, working overtime), but also perceived distress (e.g., depressive symptoms) arising from such life circumstances have emerged as risk factors of CVD. ${ }^{7}$ - Fig. 1 shows a conceptual model of how stress may be linked to prothrombotic states and thrombosis.

Importantly, the stress response (e.g., the magnitude of an increase in clotting factor activity) is not a direct indicator of stress exposure, but needs to consider higher level of cortical information processing, such as cognitive appraisal. ${ }^{20}$ The amount of threat and challenge a person appraises depends upon the predictability of the stressor and perceived coping resources (e.g., controllability of the situation), which will ultimately influence the intensity and duration of the stress response. ${ }^{21}$ For example, healthy men who reported greater 


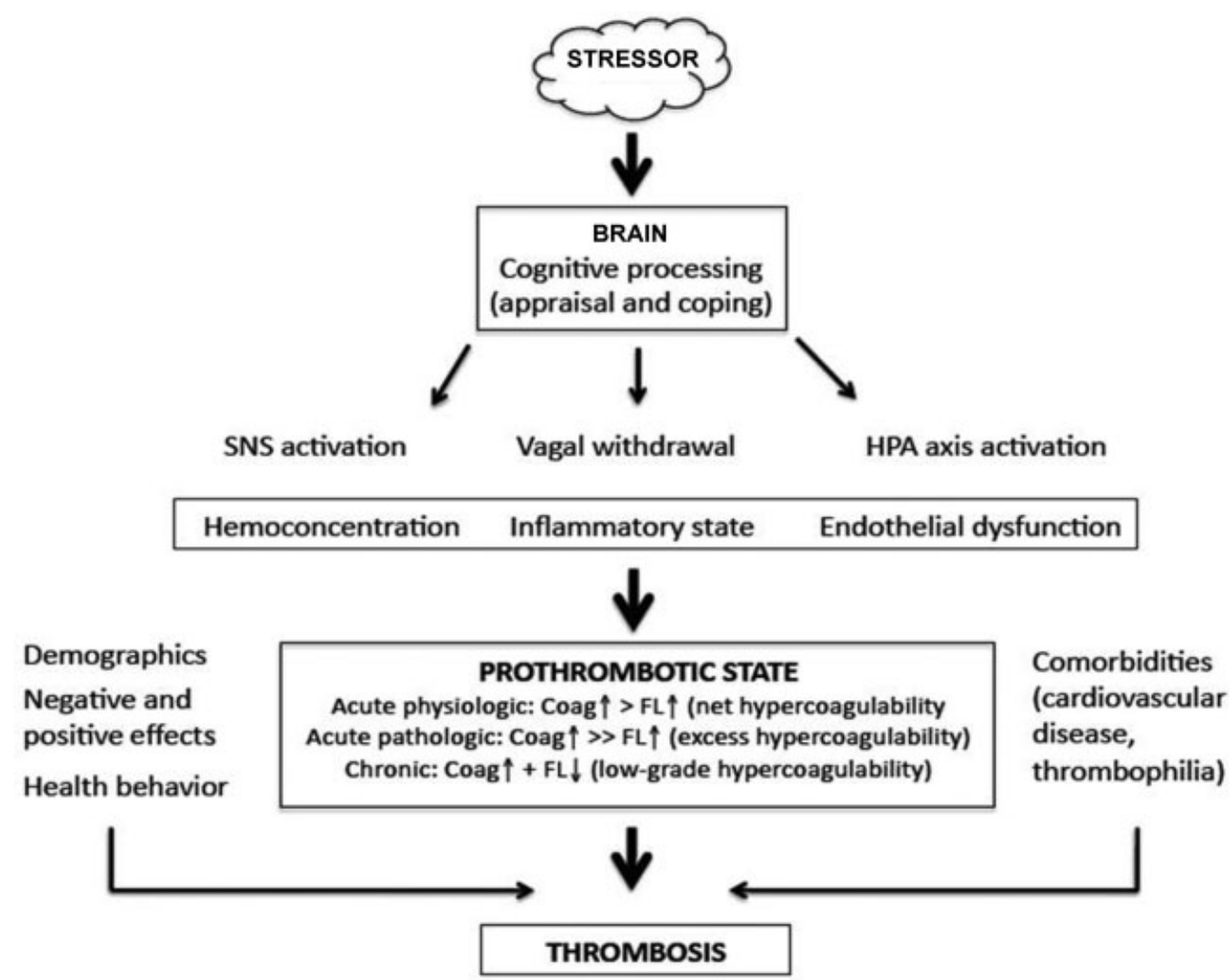

Fig. 1 Processes in the relationship between stress, hemostasis, and thrombosis. Depending on cortical information processing and appraised coping resources, environmental challenges initiate autonomic- and neuroendocrine-driven changes in the hemostatic system. Several demographic and health-related factors modulate and acquired prothrombotic conditions enhance the prothrombotic stress response, which may become pathological if excessive or chronic, thereby increasing thrombosis risk. Coag, coagulation activation; FL, fibrinolysis activation; HPA, hypothalamic-pituitary-adrenal axis; SNS, sympathetic nervous system ( $\uparrow=$ increased, $\downarrow=$ decreased).

stress appraisal had greater increase and longer recovery of D-dimer levels over a 1-hour period following the Trier Social Stress Test (TSST), which combines a mock job interview with mental arithmetic in front of an audience for a total of 15 minutes. $^{22}$

A role of the brain in shaping the procoagulant stress response is further evidenced by imaging studies showing corticolimbic brain areas to be jointly involved in processing stressors and regulating hemodynamic stress responses pertinent to CVD risk. ${ }^{23}$ Congruent with these neuroimaging studies, early studies demonstrated that electrical stimulation of the lateral hypothalamus in dogs resulted in elevated clotting factor VIII activity (FVIII:C), whereas decreased FVIII:C was observed if the hippocampus was stimulated, with effects lasting approximately 1 hour. ${ }^{24}$ Moreover, brain serotonergic neurotransmission dysfunction is evident in stress-related mental disorders such as depression and anxiety. Platelets of depressed and anxious individuals show heightened responses to serotonin. ${ }^{25,26}$ Moreover, the $5-\mathrm{HT}_{2 \mathrm{~A}}$ receptors in platelets and brain neurons share similarities with the same gene encoding for the platelet and brain serotonin transporter. ${ }^{27}$ A brain-platelet-coronary artery interface was proposed, whereby serotonergic dysfunction related to stress might increase the risk of coronary thrombosis through platelet activation. $^{28}$

\section{Acute Stress and Hemostasis}

\section{Studies in Healthy Individuals}

Numerous studies have investigated changes in hemostasis factors in response to acute psychosocial stressors applied in naturalistic and laboratory settings (-Table $\mathbf{1}$ ), the latter using standardized speech tasks, mental arithmetic, mirror star tracing task, and the Stroop color-word conflict test. In healthy individuals, there is an increase in procoagulant markers, namely, FVII:C, FVIII:C, FXII:C, fibrinogen, platelets, and von Willebrand factor antigen (VWF:Ag), and of profibrinolytic t-PA indicating, on the whole, concomitant activation of coagulation and fibrinolysis pathways with acute psychosocial stress. ${ }^{1,4,5,7,18,19}$ Levels of the coagulation activation markers thrombin-antithrombin complex (TAT) and D-dimer increase as well. ${ }^{22,29}$ Thus, both coagulation and fibrinolysis increase during acute stress, but coagulation increases more than fibrinolysis, resulting in net hypercoagulability. Activity of several clotting factors (FVII:C, FVIII:C, FXII:C) as well as fibrinogen and VWF:Ag levels increased between 5 and 10\% in response to acute stress in healthy subjects; this change was reproducible across three testings with 1 -week intervals. ${ }^{30}$ Accordingly, percent prothrombin time (PT\%) significantly increased (i.e., indicating activation of the extrinsic coagulation pathway) and activated partial 
Table 1 Reliable changes in hemostasis factors with stress observed in several studies

\begin{tabular}{|l|l|l|}
\hline Measure & $\begin{array}{l}\text { Acute } \\
\text { stress }\end{array}$ & $\begin{array}{l}\text { Chronic } \\
\text { stress }\end{array}$ \\
\hline Fibrinogen & $\uparrow$ & $\uparrow$ \\
\hline Factor XII:C & $\uparrow$ & $?$ \\
\hline Factor VII:C & $\uparrow$ & $\uparrow$ \\
\hline Factor VIII:C & $\uparrow$ & $\uparrow$ \\
\hline von Willebrand factor antigen & $\uparrow$ & $\uparrow$ \\
\hline Platelet activity & $\uparrow$ & $\uparrow$ \\
\hline Thrombin-antithrombin complex & $\uparrow$ & $?$ \\
\hline Fibrin D-dimer & $\uparrow$ & $\uparrow$ \\
\hline Percent prothrombin time & $\uparrow$ & $?$ \\
\hline $\begin{array}{l}\text { Activated partial } \\
\text { thromboplastin time }\end{array}$ & $\downarrow$ & - \\
\hline $\begin{array}{l}\text { Tissue-type plasminogen } \\
\text { activator activity }\end{array}$ & $\uparrow$ & $\downarrow$ \\
\hline $\begin{array}{l}\text { Tissue-type plasminogen } \\
\text { activator antigen }\end{array}$ & $?$ & $\uparrow$ \\
\hline $\begin{array}{l}\text { Plasminogen activator } \\
\text { inhibitor-1 (antigen and activity) }\end{array}$ & - & $\uparrow$ \\
\hline
\end{tabular}

Notes: Qualitative changes ( $\uparrow$, increased level; $\downarrow$, decreased level; - , no change; ?, unclear). While there is coagulation and platelet activation in both acute and chronic stress conditions, fibrinolysis is activated with acute stress but attenuated with chronic stress.

thromboplastin time (aPTT) significantly decreased (i.e., indicating activation of the intrinsic coagulation pathway) during the TSST in healthy men between 20 and 50 years of age. ${ }^{31}$ In agreement with the fight-or-flight response that protects organisms for a limited time, coagulation and platelet activity return to prestress levels within 20 to 45 minutes after termination of a laboratory stressor. ${ }^{30,32,33}$

\section{Modulating Factors of the Acute Prothrombotic Stress Response}

Several sociodemographic, health-related, psychosocial, and behavioral factors are associated with excessive and prolonged hypercoagulability and thus might adversely impact vascular health (-Fig. 1). Age was positively associated with an increase in D-dimer levels during stress and 20 minutes poststress, ${ }^{33}$ suggesting that the risk for stress-triggered thrombosis may be increased in elderly people. Men experienced greater net stress-hypercoagulability than women, indexed by a greater FVII:C increase to acute stress in men and greater t-PA activity in women. ${ }^{34,35}$ Among those of low SES the stress-induced increase in FVIII: $\mathrm{C}$ remained elevated 45 minutes poststress, whereas FVIII: $C$ returned to baseline levels among intermediate- and high-SES individuals. ${ }^{36}$

Compared with individuals free of CVD, those with coronary heart disease (CHD) and/or systemic hypertension showed greater platelet activation, ${ }^{32,37}$ delayed recovery of platelet activity, ${ }^{32}$ greater D-dimer increase, ${ }^{38}$ delayed recov- ery of declined (i.e., consumed) antithrombin III, $^{39}$ and reduced fibrinolysis activation, ${ }^{40}$ all in response to acute stress.

Chronic stress and negative effects were also shown to exaggerate the acute prothrombotic stress response. For instance, men with higher job stress showed greater VWF:Ag response to acute stress. ${ }^{41}$ In caregivers of a spouse with dementia, the number of negative life events during the last month correlated directly with changes in a prothrombotic score comprising procoagulant factors (i.e., TAT, D-dimer, VWF:Ag, t-PA:Ag) and antifibrinolytic plasminogen activator inhibitor (PAI)-1:Ag during speech stress. ${ }^{42}$ In caregivers, but not in controls, depressive and anxiety symptoms were also related to increased expression and delayed recovery of platelet P-selectin with acute stress, controlling for age, sex, history of CHD, and use of aspirin and antidepressants. ${ }^{43}$

Factors associated with good cardiovascular health (e.g., positive effects and a diet rich in catechins) may favorably affect (i.e., mitigate) the prothrombotic stress response. Greater happiness over a working day was associated with lower fibrinogen responses to color-word interference and mirror tracing tasks after adjustment for sociodemographic and CVD risk factors. ${ }^{44}$ Finally, platelet activation during acute stress was reduced after 6 weeks of black tea intake (i.e., increased catechin consumption) relative to placebo treatment. $^{45}$

\section{Underlying Physiological Mechanisms with Acute Stress}

The sympathetic nervous system (SNS) exerts major effects on hemostasis at times of acute stress. ${ }^{46}$ A previous systematic review of human studies examined hemostatic changes after infusions of adrenergic compounds with and without administration of adrenergic blockers. ${ }^{47}$ Catecholamines, particularly epinephrine, stimulate vascular endothelial $\beta_{2}$ adrenergic receptors within a few minutes and in a dosedependent fashion, resulting in release of preformed FVIII, VWF, and t-PA from endothelial storage pools into the circulation. ${ }^{47}$ Catecholamines also stimulate hepatic release of FVIII and affect hepatic clearance of t-PA and likely of Ddimer. Sympathetic nerves in densely innervated resistance arteries and arterioles are another important source of acute stress-induced release of t-PA into the circulation. ${ }^{48}$ Moreover, greater sensitivity of the $\beta_{2}$-adrenergic receptor and norepinephrine increase were both associated with increased TAT levels during acute stress, ${ }^{29}$ and there was a direct relationship between stress-induced increases in norepinephrine and D-dimer. ${ }^{22}$ Stress-induced change in D-dimer was significantly associated with change in FVII:C, explaining $43 \%$ of the mutual variance, but not with change in fibrinogen, FVIII:C, FXII:C, VWF:Ag, or soluble tissue factor (sTF). ${ }^{49}$ Consistent with SNS overactivity observed in hypertensive individuals, infusion of the nonselective $\beta$-receptor agonist isoproterenol resulted in greater increase of plasma VWF in hypertensives than in normotensives. ${ }^{50}$

Thrombin is a potent platelet agonist, and if formed during stress, might critically contribute to platelet activation in vivo. ${ }^{29}$ During acute stress, platelets are activated by stimulation of their $\alpha_{2}$-adrenergic receptors, whereby stimulation 
of their $\beta_{2}$-adrenergic receptors seems to exert platelet inhibition. ${ }^{47}$ Compared with normotensives, patients with essential hypertension showed greater platelet activation (i.e., greater platelet size, increased plasma $\beta$-thromboglobulin [ $\beta T G]$ levels) to a physiological dose of infused epinephrine. ${ }^{51}$

In addition to SNS-related mechanisms governing acute hemostatic stress responses, plasma volume contraction (i.e., hemoconcentration) also influences hemostatic measures during acute stress. In healthy individuals, this stress-hemoconcentration is facilitated by an acute increase in blood pressure and net efflux of plasma into the interstitial spaces, thereby resulting in an elevated intravascular concentration of nondiffusible blood constituents (i.e., greater than $69 \mathrm{kDa}$ ), including fibrinogen, prothrombin, FV, FVIII, FXI, FXII, and the VWF. $^{7}$ The mechanisms underlying stress-hemoconcentration in patients with CHD are less clear. ${ }^{52}$ Acute stressinduced changes in plasma volume only explain between 4 and $10 \%$ of the variance in changes of FVII:C, FVIII:C, and FXII: $\mathrm{C}^{49}$ The most accurate methods to investigate the relative contribution of stress-hemoconcentration to the acute prothrombotic stress response are of current debate. ${ }^{53-55}$ Arithmetic adjustment for stress-hemoconcentration has differing effects on fibrinogen, FVII:C, FVIII:C, FXII:C, VWF:Ag, PT\%, and aPTT. $^{31,56}$ Saline reconstitution of contracted plasma suggested that stress-induced elevations of most measures was due to hemoconcentration, with the notable exception of FVIII:C. ${ }^{31}$ In fact, no correction technique removed the effects for FVIII:C, suggesting that the intrinsic pathway is genuinely activated during acute stress. ${ }^{31,56}$

Other psychobiological processes contributing to emotional triggering of ACS include stress-induced hemodynamic shear forces to a vulnerable plaque and inflammatory responses involving cytokines further destabilizing plaques. ${ }^{57}$ Moreover, the hemostatic and inflammatory systems are associated during stress. After the TSST, D-dimer and interleukin (IL)-6 reactivity showed a significant and positive correlation over a 2-hour period. ${ }^{58}$

\section{Chronic Stress and Hemostasis}

Different domains of chronic psychosocial stress and distress (e.g., SES, job stress, caregiver stress, posttraumatic stress disorder [PTSD]) have been associated with hemostatic alterations. Similar to acute stress, procoagulant markers, particularly fibrinogen, D-dimer, FVII:C, FVIII:C, and VWF:Ag, are increased by chronic stress (-Table 1). ${ }^{4,5,19}$ Importantly, opposed to acute stress, chronic stress seems to impair fibrinolytic activity, reflected by increased PAI-1:Ag, PAI-1 activity, and t-PA:Ag, but decreased t-PA activity. Thus, chronic stress shifts the hemostatic balance between coagulation and fibrinolysis toward a chronic low-grade hypercoagulable state potentially increasing risk of thrombotic disease. ${ }^{4,5,19}$

\section{Low Socioeconomic Status}

Low SES can be construed as a state of chronic stress. ${ }^{59}$ Substantial evidence supports a relationship between low SES as measured by different constructs (e.g., education, occupational class, and social class) and elevated levels of fibrinogen, FVII:C, and VWF:Ag. ${ }^{4} \mathrm{~A}$ large meta-analysis revealed higher fibrinogen levels in unemployed persons than in employed workers, as well as in individuals with lower versus higher education, controlling for a range of CVD risk factors. ${ }^{60}$

\section{Job Stress}

Stress at work-defined as a mismatch between job demands and decision latitude (i.e., high job strain) ${ }^{61}$ or as an imbalance between effort spent and reward obtained ${ }^{62}$-has been associated with elevated fibrinogen and FVII:C and reduced fibrinolytic capacity (i.e., decreased t-PA activity and increased PAI1:Ag), mainly in cross-sectional studies. ${ }^{4}$ Accountants showed increased FVII:C, FVIII:C, and fibrinogen as well as exaggerated adenosine diphosphate (ADP)- and thrombin-induced platelet aggregation, but no difference in PT and aPTT, during a period of increased work load relative to a calmer period. ${ }^{63}$ In male Korean workers with high job strain, FVIII:C, but not FVII:C, was increased after controlling for smoking, blood pressure, and lipids. ${ }^{64} \mathrm{~A}$ recent review suggests that the relation between an adverse psychosocial working environment and elevated fibrinogen is a robust one. ${ }^{65}$

\section{Caregiver Stress}

Providing in-home informal care to a demented spouse is a natural model of chronic human stress. We found higher resting D-dimer levels in Alzheimer caregivers than in ageand sex-matched noncaregiving controls, controlling for history of CHD, CVD risk factors, lifestyle, and medications. ${ }^{66}$ Elevated D-dimer levels among caregivers were directly associated with norepinephrine and perturbed sleep measured by polysomnography. ${ }^{67,68}$ Problem behaviors of the spouse with dementia were associated with a procoagulant index that included VWF:Ag, PAI-1:Ag, and D-dimer in the caregiver. ${ }^{69}$ After the care recipient was deceased or placed in a long-term care facility, D-dimer levels in caregivers did not return to levels of noncaregiving controls until 6 to 30 months after the transition. ${ }^{70}$

\section{Posttraumatic Stress Disorder}

Typically, patients with PTSD reexperience aspects of a traumatic event, such as combat, accidents, and MI in thoughts or dreams, and avoid cues/activities reminding them of the event and develop hyperarousal symptoms, such as irritability and insomnia, all during at least 1 month. Following an accident, patients with PTSD had significantly higher levels of sTF than those who did not develop PTSD. ${ }^{71}$ Reexperiencing and avoidance symptoms as well as total PTSD symptoms also showed direct associations with $\mathrm{STF}^{71}$ while hyperarousal and total PTSD symptoms were directly associated with plasma fibrinogen levels. ${ }^{72}$ Among civilians with war-related chronic PTSD, VWF:Ag levels were significantly higher than in non-PTSD controls; additionally, the most severe PTSD cases had higher VWF:Ag and FVIII:C than those with less severe PTSD symptoms and controls. ${ }^{73}$ Conversely, PTSD symptomatology was unrelated to baseline levels of PT, aPTT, FVII:C, D-dimer, fibrinopeptide $A$, and prothrombin fragments $1+2$ across several studies. ${ }^{72-74}$ Baseline platelet activity and soluble 
P-selectin did not differ between combat veterans with and without PTSD ${ }^{75}$; however, platelets from PTSD patients showed exaggerated reactivity to in vitro epinephrine/ADP stimulation mediated by the $\alpha_{2}$-adrenergic receptor. ${ }^{76}$ Post-MI patients with PTSD caused by their MI showed a significant increase in soluble P-selectin during a trauma interview compared with non-PTSD controls ${ }^{77}$ and increased fibrinogen and D-dimer reactivity if perceived stress before the interview was high. $^{74}$

\section{Psychological Distress}

Psychological distress can be conceptualized as a maladaptive behavioral response in the form of negative effects, such as depressive and anxiety symptoms both of which may reach a degree that qualifies for a clinical/psychiatric diagnosis (e.g., major depression, panic disorder). ${ }^{9}$ Depression has been associated with an increased platelet activity ${ }^{78}$ and elevated fibrinogen levels ${ }^{19}$ in numerous studies. Patients with ACS and clinical depression showed higher plasma levels of platelet releasing factors (platelet factor 4, $\beta$ TG) compared with ACS patients without clinical depression. ${ }^{79}$ Two prospective studies showed direct correlations between depressive symptom scores and fibrinogen levels across five annual assessments in women ${ }^{80}$ and across two annual assessments in teachers. ${ }^{81}$ Higher self-rated distress was associated with greater fibrinogen levels in a large sample of healthy young adults, controlling for a range of important confounders. ${ }^{82}$ Plasma levels of PAI-1 activity were also greater in depressed than nondepressed individuals, independent of traditional CVD risk factors and status of CHD. ${ }^{83}$

In patients with previous VTE referred for diagnostic thrombophilia work up, we showed a direct association of depressive symptoms with TAT levels and, in those with low perceived social support, also with D-dimer levels, after controlling for demographic and medical covariates. ${ }^{84}$ In VTE patients, more symptoms of depression, anxiety, worrying, and anger were all associated with a reduced international normalized ratio, suggesting hastened clotting of the extrinsic coagulation pathway; worrying anger and hostility also showed a direct association with FVII:C levels. ${ }^{85}$ Interestingly, relatively lower FX:C in relation to anxiety and worrying and relatively lower FVII:C in relation to anger and hostility were observed in patients with oral anticoagulant (OAC) therapy compared with those without. ${ }^{85}$ This difference might be explained by a stress-related innate immune response ${ }^{86}$ that attenuates the metabolism of OACs to increase inhibition of vitamin K-dependent clotting factors. ${ }^{87}$

Predominantly impaired fibrinolysis (i.e., increased PAI-1: $\mathrm{Ag}$ and $\alpha_{2}$-antiplasmin levels) has been found in patients with an anxiety disorder. ${ }^{88}$ Moreover, similar to healthy controls, those anxiety patients medicated with a serotonergic antidepressant showed lower fibrinogen and PAI-1:Ag levels and higher plasmin- $\alpha_{2}$-antiplasmin complex, relative to patients with no serotonergic antidepressant. ${ }^{89}$ Anxiety symptoms were associated with increased platelet reactivity to serotonin using flow cytometry in CHD patients. ${ }^{25}$ In factory workers, panic-like anxiety was associated with higher D-dimer and lower fibrinogen levels, but not PAI-1:Ag. ${ }^{90}$ However, in a population-based study, anxiety and fibrinogen levels showed a direct relation controlling for covariates. ${ }^{91}$

Additional negative affect states being associated with an increased CVD risk ${ }^{9}$ have also been associated with a prothrombotic state. For instance, early bereavement has been associated with increased levels of platelet-granulocyte aggregates, VWF:Ag and FVIII:C, but not fibrinogen, PAI-1:Ag and t-PA:Ag levels, ${ }^{92}$ whereas exhaustion has been related to increased levels of fibrinogen ${ }^{93}$ and PAI-1 activity. ${ }^{94}$

\section{Positive Effects and Related Constructs}

Positive psychological states might attenuate hypercoagulability so to buffer harmful hemostatic effects of negative effect states. However, studies on associations of positive effects and related constructs with hemostatic measures are still sparse. Dispositional optimism was associated with lowered fibrinogen levels in a multiethnic population-based study. ${ }^{95}$ Similarly, in healthy subjects, increases in uplift intensity over the past month predicted lower levels of PAI-1:Ag levels, whereas increase in distress related to hassle severity predicted elevated levels of D-Dimer. ${ }^{96}$ In women, but not in men, aged 50 years and older, greater enjoyment of life was associated with lower fibrinogen levels after controlling for a range of health characteristics, including depressed mood. ${ }^{97}$

\section{Underlying Physiological Mechanisms with Chronic Stress}

Activation of the hypothalamic-pituitary-adrenal axis and decreased parasympathetic activity (i.e., vagal withdrawal) might be more important processes underlying hypercoagulability associated with chronic stress compared with acute stress. ${ }^{5,19}$ Factory workers showed associations of overnight urinary excretion of cortisol and catecholamines with morning plasma levels of PAI-1 antigen, fibrinogen, and D-dimer. ${ }^{98}$ Plasma cortisol levels were also directly correlated with fibrinogen and VWF:Ag levels in women with stable $\mathrm{CHD}^{99}$ and with fibrinogen in middle-aged men and women. ${ }^{100}$ Lower high frequency heart rate variability (HF-HRV; indicating reduced vagal function) was associated with increased levels of PAI-1: Ag in healthy individuals ${ }^{101}$ and with fibrinogen and activated FVII in women with stable CHD, ${ }^{102}$ controlling for a range of covariates. The association of increased circulating PAI-1 levels with autonomic dysfunction in humans is supported by studies in rodents showing increased gene expression of PAI- 1 after several weeks of unpredictable chronic mild stress, ${ }^{103}$ following restraint stress, ${ }^{104}$ and after epinephrine and isoprenalin injection. ${ }^{105}$ In factory workers, night-time HF-HRV was inversely related to plasma fibrinogen levels, with a stronger relationship for women than men. ${ }^{106}$ Vagal withdrawal in chronic stress might mediate hypercoagulability in part via systemic low-grade inflammation. Cross-talk between inflammation and hemostasis plays a key role in atherosclerosis progression, ${ }^{2}$ and low-grade inflammation (e.g., increased circulating levels of IL-6 and C-reactive protein) is an important mechanism linking chronic psychosocial stress to atherosclerosis. ${ }^{107}$ In healthy men and women, there was a direct relation between plasma levels of IL-6 and STF if HF-HRV was low, but not if HF-HRV was high. ${ }^{108}$ 
Table 2 Intervention studies examining the relationship between stress and hemostasis

\begin{tabular}{|c|c|c|c|}
\hline \multirow[t]{2}{*}{ Study population } & \multirow[t]{2}{*}{ Intervention } & \multicolumn{2}{|c|}{ Outcome } \\
\hline & & Significant & Nonsignificant \\
\hline $\begin{array}{l}56 \text { healthy men and women } \\
\text { undergoing the TSST }\end{array}$ & $\begin{array}{l}\text { 5-d RCT: aspirin } 100 \mathrm{mg} \text { and/ } \\
\text { or } 80 \mathrm{mg} \text { propranolol daily } \\
\text { versus placebo }\end{array}$ & $\begin{array}{l}\text { Stress response of VWF:Ag } \downarrow \\
\text { with aspirin, propranolol, or } \\
\text { aspirin + propranolol }\end{array}$ & $\begin{array}{l}\text { Stress response of fibrinogen, } \\
\text { FVII:C, FXII:C, D-dimer }\end{array}$ \\
\hline $\begin{array}{l}54 \text { healthy men and women } \\
\text { undergoing the TSST }\end{array}$ & $\begin{array}{l}\text { 5-d RCT: aspirin } 100 \mathrm{mg} \text { and/ } \\
\text { or } 80 \mathrm{mg} \text { propranolol daily } \\
\text { versus placebo }\end{array}$ & $\begin{array}{l}\text { Stress response of FVIII:C } \downarrow \\
\text { with aspirin }+ \text { propranolol }\end{array}$ & $\begin{array}{l}\text { Stress response of FVIII:C with } \\
\text { aspirin }\end{array}$ \\
\hline $\begin{array}{l}9 \text { men and women with } \\
\text { essential hypertension } \\
\text { undergoing mental } \\
\text { arithmetic }^{109}\end{array}$ & $\begin{array}{l}\text { 12-wk RCT: benidipine } \\
2-4 \text { mg daily versus placebo }\end{array}$ & $\begin{array}{l}\text { Stress-induced platelet } \\
\text { activation } \downarrow \text { (ADP-induced } \\
\text { aggregation, } \beta T G)\end{array}$ & $\begin{array}{l}\text { Serotonin-induced platelet } \\
\text { aggregation }\end{array}$ \\
\hline $\begin{array}{l}13 \text { men and women with } \\
\text { essential hypertension } \\
\text { undergoing mental } \\
\text { arithmetic and Stroop }\end{array}$ & $\begin{array}{l}\text { 4-wk RCT: verapamil } \\
240-480 \text { mg daily versus } \\
\text { placebo }\end{array}$ & $\begin{array}{l}\text { Stress response of ADP-in- } \\
\text { duced platelet aggregation } \downarrow\end{array}$ & $\begin{array}{l}\text { Stress response of VWF:Ag, } \\
\text { t-PA:Ag, } \\
\text { PAl-1:Ag }\end{array}$ \\
\hline $\begin{array}{l}45 \text { healthy men undergoing } \\
\text { the TSST }{ }^{111}\end{array}$ & $\begin{array}{l}\text { RCT: single dose of } 3 \mathrm{mg} \\
\text { melatonin versus placebo }\end{array}$ & Stress response of D-dimer $\downarrow$ & $\begin{array}{l}\text { Stress responses of } \\
\text { fibrinogen, FVII:C, FVIII:C }\end{array}$ \\
\hline $\begin{array}{l}16 \text { men and women with } \\
\text { essential hypertension } \\
\text { undergoing the Stroop }\end{array}$ & $\begin{array}{l}\text { 6-wk RCT: ramipril } 5 \text { mg daily } \\
\text { versus placebo }\end{array}$ & & $\begin{array}{l}\text { Stress responses of TAT, } \\
\text { fibrinogen, activated FVII }\end{array}$ \\
\hline $\begin{array}{l}21 \text { men with } \\
\text { hypercholesteremia } \\
\text { undergoing the Stroop }{ }^{113}\end{array}$ & $\begin{array}{l}\text { 10-12-wk RCT: simvastatin } \\
20 \text { mg daily versus placebo }\end{array}$ & & $\begin{array}{l}\text { Stress responses of platelet } \\
\text { aggregation, } \beta T G\end{array}$ \\
\hline $\begin{array}{l}21 \text { men with } \\
\text { hypercholesteremia } \\
\text { undergoing the Stroop }{ }^{114}\end{array}$ & $\begin{array}{l}\text { 10-12-wk RCT: gemfibrozil } \\
600 \text { mg twice daily versus } \\
\text { placebo }\end{array}$ & $\begin{array}{l}\text { Stress response of platelet } \\
\text { aggregation } \uparrow\end{array}$ & Stress response of $\beta T G$ \\
\hline $\begin{array}{l}64 \text { postacute coronary } \\
\text { syndrome patients } 115\end{array}$ & $\begin{array}{l}\text { 24-wk RCT: sertraline } \\
50-200 \text { mg daily versus } \\
\text { placebo }\end{array}$ & $\beta T G \downarrow$, sP-sel $\downarrow$ & Platelet factor 4 \\
\hline $\begin{array}{l}57 \text { patients with stable CHD } \\
\text { and current major } \\
\text { depression } 116\end{array}$ & $\begin{array}{l}\text { 12-wk RCT: citalopram } \\
20-40 \mathrm{mg} \text { daily versus } \\
\text { placebo }\end{array}$ & & $\beta T G$, sP-sel \\
\hline $\begin{array}{l}108 \text { depressed men and } \\
\text { women, } 45 \text { controls } 117\end{array}$ & $\begin{array}{l}\text { 6-mo outpatient } \\
\text { psychotherapy and/or } \\
\text { antidepressants }\end{array}$ & $\begin{array}{l}\text { CD62p and CD63 positive } \\
\text { platelets } \downarrow \text {, } \\
\text { CD63 exposure on platelets } \\
\text { after ADP activation } \downarrow \text {, } \\
\text { large platelet microparticles } \downarrow\end{array}$ & $\begin{array}{l}\text { CD62p exposure to } \\
\text { ADP-stimulation, platelet- } \\
\text { leukocyte aggregates }\end{array}$ \\
\hline $\begin{array}{l}12 \text { men and women with a } \\
\text { severe anxiety disorder and } \\
\text { depression } 118\end{array}$ & $\begin{array}{l}\text { 8-wk inpatient psychotherapy } \\
\text { with or without psychotropic } \\
\text { medication }\end{array}$ & $\begin{array}{l}\text { FVII:C } \downarrow \\
\text { PAI-1:Ag } \downarrow\end{array}$ & VWF:Ag \\
\hline $\begin{array}{l}159 \text { women with stable } \\
\text { CHD }^{119}\end{array}$ & $\begin{array}{l}\text { 1-y cognitive behavioral } \\
\text { stress management } \\
\text { ( } 20 \text { 2-h sessions) versus } \\
\text { usual care }\end{array}$ & & $\begin{array}{l}\text { Fibrinogen, VWF:Ag, PAl-1: } \\
\text { Act, t-PA:Act, t-PA:Ag, t-PA/ } \\
\text { PAl-1 complex }\end{array}$ \\
\hline 18 healthy individuals ${ }^{120}$ & $\begin{array}{l}\text { 30-min comedy movie } \\
\text { provoking laughter }\end{array}$ & sP-sel $\downarrow$ & $\begin{array}{l}\text { Fibrinogen } \\
\text { VWF:Ag }\end{array}$ \\
\hline
\end{tabular}

Abbreviations: Act, activity; ADP, adenosine diphosphate; Ag, antigen level; $\beta T G$, $\beta$-thromboglobulin; CHD, coronary heart disease; d, day; FVII:C, clotting factor VII activity; h, hour; PAI, plasminogen activator inhibitor; RCT, randomized controlled trial; sP-sel, soluble P-selectin; t-PA, tissue-type plasminogen activator; TAT, thrombin-antithrombin complex; TSST, Trier Social Stress Test; VWF, von Willebrand factor; wk, week(s); y, year(s). Note: Quantitative changes ( $\downarrow$, decreased level; $\uparrow$, increased level).

\section{Results from Intervention Studies}

The few randomized placebo-controlled trials testing whether cardiovascular medications and antidepressants reduce the prothrombotic state associated with acute and chronic stress are shown in - Table 2. Even fewer in number are behavioral intervention studies targeting prothrombotic measures. Compared with placebo, the stress response of some prothrombotic 
measures was mitigated by aspirin, ${ }^{109,110}$ propranolol, ${ }^{109,110}$ calcium antagonists, ${ }^{111,112}$ and melatonin. ${ }^{113}$ Conversely, angiotensin converting enzyme inhibitor ${ }^{114}$ and statin ${ }^{115}$ administration were both ineffective and fibrate therapy even increased platelet activation during acute stress. ${ }^{116}$ However, these findings are limited by small sample sizes and heterogeneity of study populations. Selective serotonin reuptake inhibitors significantly reduced platelet activation in CHD patients in two sudies, ${ }^{117,118}$ but the decrease in $\beta$ TG levels was similar to that achieved by placebo in one of these studies. ${ }^{118}$

In- and outpatient psychiatric treatment (psychotherapy and/ or psychotropic medication) for patients with anxiety and/or depressive disorders resulted in a decrease of some platelet activation markers ${ }^{119}$ and of VWF:Ag and FVII:C. ${ }^{120}$ Moreover, reductions in depressive symptoms and platelet activation were significantly correlated with each other after 6 months of outpatient psychiatric therapy for depression. ${ }^{119}$ In contrast, cognitive behavioral stress management had no effect on several hemostasis measures in CHD patients when compared with usual care after 1 year. ${ }^{121}$ The systematic provocation of laughter might also benefit low-grade hypercoagulability. ${ }^{122}$

\section{Conclusions}

A truly physiological prothrombotic stress response is part of fight-or-flight response, but can be excessive in vulnerable individuals under acute stress and become chronic in persons unable to cope with ongoing life demands. Plausible neurobiological, neuroendocrine, and autonomic processes have been identified to partially explain how stress affects hemostasis. This knowledge underscores the notion that stress should be considered an important preanalytical confound of coagulation tests ${ }^{123}$ and a reason for fluctuations in the international normalized ratio in patients under OAC therapy. ${ }^{85}$ However, clinical implications likely reach much further. Given that hemostasis is important in atherothrombotic disease and VTE, a prothrombotic state seems a conceivable mechanism linking stress to thrombotic manifestations. To support this assumption, prospective studies are needed to demonstrate the predictive value of acute and chronic prothrombotic stress responses for incident and recurrent thrombotic events in healthy individuals and patients with CHD and VTE. Some small studies suggest that medications and perhaps behavioral interventions have the potential to attenuate the prothrombotic stress response. ${ }^{109-113,117-120}$ To potentially prevent emotional triggering of atherothrombotic events, stress management, relaxation, emotion regulation, and even medication in an effort to sever the link between stress and pathophysiological consequences have been proposed. $^{124}$ More controlled studies are warranted to investigate whether behavioral and/or medication interventions reduce stress-related hypercoagulability and subsequent thrombotic risk.

\section{Acknowledgments}

The authors are grateful to Annette Kocher for the editorial support. Roland von Känel dedicates this article to his former doctoral thesis supervisor and director of the Department of Hematology, Bern University Hospital, Switzerland, Prof. Dr. Bernhard Lämmle, on the occasion of his retirement.

\section{References}

1 Thrall G, Lane D, Carroll D, Lip GY. A systematic review of the effects of acute psychological stress and physical activity on haemorheology, coagulation, fibrinolysis and platelet reactivity: Implications for the pathogenesis of acute coronary syndromes. Thromb Res 2007;120(6):819-847

2 Borissoff JI, Spronk HM, ten Cate H. The hemostatic system as a modulator of atherosclerosis. N Engl J Med 2011;364(18): $1746-1760$

3 Lippi G, Franchini M, Favaloro EJ. Unsuspected triggers of venous thromboembolism-trivial or not so trivial? Semin Thromb Hemost 2009;35(7):597-604

4 von Känel R, Mills PJ, Fainman C, Dimsdale JE. Effects of psychological stress and psychiatric disorders on blood coagulation and fibrinolysis: a biobehavioral pathway to coronary artery disease? Psychosom Med 2001;63(4):531-544

5 von Känel R, Bacon SL. Hemostasis and endothelial function. In: Waldstein SR, Kop WJ, Katzel LI, eds. Cardiovascular Behavioral Medicine. New York, NY: Springer; 2013

6 Strike PC, Magid K, Whitehead DL, Brydon L, Bhattacharyya MR, Steptoe A. Pathophysiological processes underlying emotional triggering of acute cardiac events. Proc Natl Acad Sci U S A 2006; 103(11):4322-4327

7 Austin AW, Patterson SM, von Känel R. Hemoconcentration and hemostasis during acute stress: interacting and independent effects. Ann Behav Med 2011;42(2):153-173

8 Steptoe A, Kivimäki M. Stress and cardiovascular disease: an update on current knowledge. Annu Rev Public Health 2013; 34:337-354

9 von Känel R. Psychosocial stress and cardiovascular risk : current opinion. Swiss Med Wkly 2012;142:0

10 Yusuf S, Hawken S, Ounpuu S, et al; INTERHEART Study Investigators. Effect of potentially modifiable risk factors associated with myocardial infarction in 52 countries (the INTERHEART study): case-control study. Lancet 2004;364(9438):937-952

11 Rosengren A, Fredén M, Hansson PO, Wilhelmsen L, Wedel H, Eriksson H. Psychosocial factors and venous thromboembolism: a long-term follow-up study of Swedish men. J Thromb Haemost 2008;6(4):558-564

12 Holst AG, Jensen G, Prescott E. Risk factors for venous thromboembolism: results from the Copenhagen City Heart Study. Circulation 2010;121(17):1896-1903

13 Enga KF, Brækkan SK, Hansen-Krone IJ, Hansen JB. Emotional states and future risk of venous thromboembolism: the Tromsø Study. Thromb Haemost 2012;107(3):485-493

14 Watanabe H, Kodama M, Tanabe N, et al. Impact of earthquakes on risk for pulmonary embolism. Int J Cardiol 2008;129(1):152-154

15 Schobersberger W, Schobersberger B, Mittermayr M, Fries D, Streif W. Air travel, hypobaric hypoxia, and prothrombotic changes. JAMA 2006;296(19):2313-2314, author reply 23142315

16 Goldhaber SZ. Risk factors for venous thromboembolism. J Am Coll Cardiol 2010;56(1):1-7

17 Lee KW, Lip GY. Effects of lifestyle on hemostasis, fibrinolysis, and platelet reactivity: a systematic review. Arch Intern Med 2003; 163(19):2368-2392

18 Brydon L, Magid K, Steptoe A. Platelets, coronary heart disease, and stress. Brain Behav Immun 2006;20(2):113-119 
19 Hjemdahl P, von Känel R. Haemostatic effects of stress. In: Hjemdahl P, Rosengren A, Steptoe A, eds. Stress and Cardiovascular Disease. London, England: Springer; 2012:89-110

20 Koolhaas JM, Bartolomucci A, Buwalda B, et al. Stress revisited: a critical evaluation of the stress concept. Neurosci Biobehav Rev 2011;35(5):1291-1301

21 Lazarus RS, Folkman S. Stress, Appraisal, and Coping. New York, NY: Springer; 1984

22 Wirtz PH, Ehlert U, Emini L, et al. Anticipatory cognitive stress appraisal and the acute procoagulant stress response in men. Psychosom Med 2006;68(6):851-858

23 Gianaros PJ, Sheu LK. A review of neuroimaging studies of stressor-evoked blood pressure reactivity: emerging evidence for a brain-body pathway to coronary heart disease risk. Neuroimage 2009;47(3):922-936

24 Gunn CG, Hampton JW. CNS influence on plasma levels of factor 8 activity. Am J Physiol 1967;212(1):124-130

25 Shimbo D, Child J, Davidson K, et al. Exaggerated serotoninmediated platelet reactivity as a possible link in depression and acute coronary syndromes. Am J Cardiol 2002;89(3):331-333

26 Zafar MU, Paz-Yepes M, Shimbo D, et al. Anxiety is a better predictor of platelet reactivity in coronary artery disease patients than depression. Eur Heart J 2010;31(13):1573-1582

27 Lesch KP, Wolozin BL, Murphy DL, Reiderer P. Primary structure of the human platelet serotonin uptake site: identity with the brain serotonin transporter. J Neurochem 1993;60(6):2319-2322

28 Becker RC. Editor's page: fundamentals in neurocardiology: the brain-platelet-coronary artery interface. J Thromb Thrombolysis 2008;26(1):74-77

29 von Känel R, Mills PJ, Ziegler MG, Dimsdale JE. Effect of beta2adrenergic receptor functioning and increased norepinephrine on the hypercoagulable state with mental stress. Am Heart J 2002;144(1):68-72

30 von Känel R, Preckel D, Zgraggen L, et al. The effect of natural habituation on coagulation responses to acute mental stress and recovery in men. Thromb Haemost 2004;92(6):1327-1335

31 Austin AW, Wirtz PH, Patterson SM, Stutz M, von Känel R. Stressinduced alterations in coagulation: assessment of a new hemoconcentration correction technique. Psychosom Med 2012;74(3): 288-295

32 Strike PC, Magid K, Brydon L, Edwards S, McEwan JR, Steptoe A. Exaggerated platelet and hemodynamic reactivity to mental stress in men with coronary artery disease. Psychosom Med 2004;66(4):492-500

33 Wirtz PH, Redwine LS, Baertschi C, Spillmann M, Ehlert U, von Känel R. Coagulation activity before and after acute psychosocial stress increases with age. Psychosom Med 2008;70(4):476-481

34 Jern C, Eriksson E, Tengborn L, Risberg B, Wadenvik H, Jern S. Changes of plasma coagulation and fibrinolysis in response to mental stress. Thromb Haemost 1989;62(2):767-771

35 Jern C, Manhem K, Eriksson E, Tengborn L, Risberg B, Jern S. Hemostatic responses to mental stress during the menstrual cycle. Thromb Haemost 1991;66(5):614-618

36 Steptoe A, Kunz-Ebrecht S, Owen N, et al. Socioeconomic status and stress-related biological responses over the working day. Psychosom Med 2003;65(3):461-470

37 Wallén NH, Held C, Rehnqvist N, Hjemdahl P. Effects of mental and physical stress on platelet function in patients with stable angina pectoris and healthy controls. Eur Heart J 1997;18(5): 807-815

38 von Känel R, Dimsdale JE, Ziegler MG, et al. Effect of acute psychological stress on the hypercoagulable state in subjects (spousal caregivers of patients with Alzheimer's disease) with coronary or cerebrovascular disease and/or systemic hypertension. Am J Cardiol 2001;87(12):1405-1408

39 Canevari A, Tacconi F, Zucchella M, Pacchiarini L, Soffiantino F, Grignani G. Antithrombin III biological activity and emotional stress in patients with coronary artery disease. Haematologica 1992;77(2):180-182

40 Palermo A, Bertalero P, Pizza N, Amelotti R, Libretti A. Decreased fibrinolytic response to adrenergic stimulation in hypertensive patients. J Hypertens Suppl 1989;7(6):S162-S163

41 Hamer M, Williams E, Vuonovirta R, Giacobazzi P, Gibson EL, Steptoe A. The effects of effort-reward imbalance on inflammatory and cardiovascular responses to mental stress. Psychosom Med 2006;68(3):408-413

42 von Känel R, Dimsdale JE, Patterson TL, Grant I. Acute procoagulant stress response as a dynamic measure of allostatic load in Alzheimer caregivers. Ann Behav Med 2003;26(1):42-48

43 Aschbacher K, Mills PJ, von Känel R, et al. Effects of depressive and anxious symptoms on norepinephrine and platelet P-selectin responses to acute psychological stress among elderly caregivers. Brain Behav Immun 2008;22(4):493-502

44 Steptoe A, Wardle J, Marmot M. Positive affect and health-related neuroendocrine, cardiovascular, and inflammatory processes. Proc Natl Acad Sci U S A 2005;102(18):6508-6512

45 Steptoe A, Gibson EL, Vuononvirta R, et al. The effects of tea on psychophysiological stress responsivity and post-stress recovery: a randomised double-blind trial. Psychopharmacology (Berl) 2007;190(1):81-89

46 Preckel D, von Känel R. Regulation of hemostasis by the sympathetic nervous system: any contribution to coronary artery disease? HeartDrug 2004;4(3):123-130

47 von Känel R, Dimsdale JE. Effects of sympathetic activation by adrenergic infusions on hemostasis in vivo. Eur J Haematol 2000; 65(6):357-369

48 Hao Z, Jiang X, Sharafeih R, et al. Stimulated release of tissue plasminogen activator from artery wall sympathetic nerves: implications for stress-associated wall damage. Stress 2005; 8(2):141-149

49 Zgraggen L, Fischer JE, Mischler K, Preckel D, Kudielka BM, von Känel R. Relationship between hemoconcentration and blood coagulation responses to acute mental stress. Thromb Res 2005; 115(3):175-183

50 von Känel R, Dimsdale JE, Adler KA, Dillon E, Perez CJ, Mills PJ. Effects of nonspecific beta-adrenergic stimulation and blockade on blood coagulation in hypertension. J Appl Physiol 2003;94(4): 1455-1459

51 Kjeldsen SE, Rostrup M, Gjesdal K, Eide I. The epinephrine-blood platelet connection with special reference to essential hypertension. Am Heart J 1991;122(1 Pt 2):330-336

52 Bacon SL, Ring C, Lip GY, Carroll D. Increases in lipids and immune cells in response to exercise and mental stress in patients with suspected coronary artery disease: effects of adjustment for shifts in plasma volume. Biol Psychol 2004;65(3):237-250

53 Fall L, Bailey DM. Interpretive limitations associated with plasma volume shifts in the clinical assessment of hemostasis. Psychosom Med 2013;75(2):222-223

54 Muldoon MF. Challenges in controlling for the effects of hematoconcentration. Psychosom Med 2013;75(2):223

55 Austin AW, Wirtz PH, Patterson SM, Stutz M, von Känel R. Reply to letters from Fall and Bailey, and Muldoon. Psychosom Med 2013; 75(2):223-226

56 von Känel R, Kudielka BM, Haeberli A, Stutz M, Fischer JE, Patterson SM. Prothrombotic changes with acute psychological stress: combined effect of hemoconcentration and genuine coagulation activation. Thromb Res 2009;123(4):622-630

57 Steptoe A, Brydon L. Emotional triggering of cardiac events. Neurosci Biobehav Rev 2009;33(2):63-70

58 von Känel R, Kudielka BM, Hanebuth D, Preckel D, Fischer JE. Different contribution of interleukin-6 and cortisol activity to total plasma fibrin concentration and to acute mental stressinduced fibrin formation. Clin Sci (Lond) 2005;109(1):61-67 
59 Kopp MS, Skrabski A, Székely A, Stauder A, Williams R. Chronic stress and social changes: socioeconomic determination of chronic stress. Ann N Y Acad Sci 2007;1113:325-338

60 Kaptoge S, White IR, Thompson SG, et al; Fibrinogen Studies Collaboration. Associations of plasma fibrinogen levels with established cardiovascular disease risk factors, inflammatory markers, and other characteristics: individual participant metaanalysis of 154,211 adults in 31 prospective studies: the fibrinogen studies collaboration. Am J Epidemiol 2007;166(8):867-879

61 Theorell T, Karasek RA. Current issues relating to psychosocial job strain and cardiovascular disease research. J Occup Health Psychol 1996;1(1):9-26

62 Siegrist J. Adverse health effects of high-effort/low-reward conditions. J Occup Health Psychol 1996;1(1):27-41

63 Frimerman A, Miller HI, Laniado S, Keren G. Changes in hemostatic function at times of cyclic variation in occupational stress. Am J Cardiol 1997;79(1):72-75

64 Chang SJ, Koh SB, Cha BS, Park JK. Job characteristics and blood coagulation factors in Korean male workers. J Occup Environ Med 2002;44(11):997-1002

65 Hansen AM, Larsen AD, Rugulies R, Garde AH, Knudsen LE. A review of the effect of the psychosocial working environment on physiological changes in blood and urine. Basic Clin Pharmacol Toxicol 2009;105(2):73-83

66 von Känel R, Dimsdale JE, Mills PJ, et al. Effect of Alzheimer caregiving stress and age on frailty markers interleukin-6, Creactive protein, and D-dimer. J Gerontol A Biol Sci Med Sci 2006; 61(9):963-969

67 von Känel R, Dimsdale JE, Ancoli-Israel S, et al. Poor sleep is associated with higher plasma proinflammatory cytokine interleukin-6 and procoagulant marker fibrin D-dimer in older caregivers of people with Alzheimer's disease. J Am Geriatr Soc 2006; 54(3):431-437

68 Mausbach BT, Ancoli-Israel S, von Känel R, et al. Sleep disturbance, norepinephrine, and D-dimer are all related in elderly caregivers of people with Alzheimer disease. Sleep 2006;29(10): 1347-1352

69 von Känel R, Mausbach BT, Dimsdale JE, et al. Problem behavior of dementia patients predicts low-grade hypercoagulability in spousal caregivers. J Gerontol A Biol Sci Med Sci 2010;65(9): 1004-1011

70 Mausbach BT, Aschbacher K, Patterson TL, et al. Effects of placement and bereavement on psychological well-being and cardiovascular risk in Alzheimer's caregivers: a longitudinal analysis. J Psychosom Res 2007;62(4):439-445

71 von Känel R, Hepp U, Traber R, et al. Measures of endothelial dysfunction in plasma of patients with posttraumatic stress disorder. Psychiatry Res 2008;158(3):363-373

72 von Känel R, Hepp U, Buddeberg C, et al. Altered blood coagulation in patients with posttraumatic stress disorder. Psychosom Med 2006;68(4):598-604

73 Robicsek O, Makhoul B, Klein E, Brenner B, Sarig G. Hypercoagulation in chronic post-traumatic stress disorder. Isr Med Assoc J 2011;13(9):548-552

74 von Känel R, Abbas CC, Schmid JP, et al. Momentary stress moderates procoagulant reactivity to a trauma-specific interview in patients with posttraumatic stress disorder caused by myocardial infarction. J Psychiatr Res 2010;44(14):956-963

75 Vidović A, Vilibić M, Markotić A, et al. Baseline level of plateletleukocyte aggregates, platelet CD63 expression, and soluble Pselectin concentration in patients with posttraumatic stress disorder: a pilot study. Psychiatry Res 2007;150(2):211-216

76 Vidović A, Grubišić-Ilić M, Kozarić-Kovačić D, et al. Exaggerated platelet reactivity to physiological agonists in war veterans with posttraumatic stress disorder. Psychoneuroendocrinology 2011; 36(2):161-172

77 von Känel R, Abbas CC, Begré S, Saner H, Gander ML, Schmid JP. Posttraumatic stress disorder and soluble cellular adhesion mol- ecules at rest and in response to a trauma-specific interview in patients after myocardial infarction. Psychiatry Res 2010;179(3): 312-317

78 von Känel R. Platelet hyperactivity in clinical depression and the beneficial effect of antidepressant drug treatment: how strong is the evidence? Acta Psychiatr Scand 2004;110(3):163-177

79 Serebruany VL, Glassman AH, Malinin AI, et al. Enhanced platelet/ endothelial activation in depressed patients with acute coronary syndromes: evidence from recent clinical trials. Blood Coagul Fibrinolysis 2003;14(6):563-567

80 Matthews KA, Schott LL, Bromberger J, Cyranowski J, EversonRose SA, Sowers MF. Associations between depressive symptoms and inflammatory/hemostatic markers in women during the menopausal transition. Psychosom Med 2007;69(2):124-130

81 Von Känel R, Bellingrath S, Kudielka BM. Association between longitudinal changes in depressive symptoms and plasma fibrinogen levels in school teachers. Psychophysiology 2009;46(3):473-480

82 Goldman-Mellor S, Brydon L, Steptoe A. Psychological distress and circulating inflammatory markers in healthy young adults. Psychol Med 2010;40(12):2079-2087

83 Lahlou-Laforet K, Alhenc-Gelas M, Pornin M, et al. Relation of depressive mood to plasminogen activator inhibitor, tissue plasminogen activator, and fibrinogen levels in patients with versus without coronary heart disease. Am J Cardiol 2006;97(9): 1287-1291

84 Lukas PS, Neugebauer A, Schnyder S, et al. Depressive symptoms, perceived social support, and prothrombotic measures in patients with venous thromboembolism. Thromb Res 2012;130(3): 374-380

85 Von Känel R, Vökt F, Biasiutti FD, Stauber S, Wuillemin WA, Lukas PS. Relation of psychological distress to the international normalized ratio in patients with venous thromboembolism with and without oral anticoagulant therapy. J Thromb Haemost 2012; 10(8):1547-1555

86 Black PH, Garbutt LD. Stress, inflammation and cardiovascular disease. J Psychosom Res 2002;52(1):1-23

87 Hawk TL, Havrda DE. Effect of stress on international normalized ratio during warfarin therapy. Ann Pharmacother 2002;36(4): 617-620

88 Geiser F, Meier C, Wegener I, et al. Association between anxiety and factors of coagulation and fibrinolysis. Psychother Psychosom 2008;77(6):377-383

89 Geiser F, Conrad R, Imbierowicz K, et al. Coagulation activation and fibrinolysis impairment are reduced in patients with anxiety and depression when medicated with serotonergic antidepressants. Psychiatry Clin Neurosci 2011;65(5):518-525

90 von Känel R, Kudielka BM, Schulze R, Gander ML, Fischer JE. Hypercoagulability in working men and women with high levels of panic-like anxiety. Psychother Psychosom 2004;73(6):353-360

91 Pitsavos C, Panagiotakos DB, Papageorgiou C, Tsetsekou E, Soldatos C, Stefanadis C. Anxiety in relation to inflammation and coagulation markers, among healthy adults: the ATTICA study. Atherosclerosis 2006;185(2):320-326

92 Buckley T, Morel-Kopp MC, Ward C, et al. Inflammatory and thrombotic changes in early bereavement: a prospective evaluation. Eur J Prev Cardiol 2012;19(5):1145-1152

93 Kudielka BM, Bellingrath S, von Känel R. Circulating fibrinogen but not D-dimer level is associated with vital exhaustion in school teachers. Stress 2008;11(4):250-258

94 Kop WJ, Hamulyák K, Pernot C, Appels A. Relationship of blood coagulation and fibrinolysis to vital exhaustion. Psychosom Med 1998;60(3):352-358

95 Roy B, Diez-Roux AV, Seeman T, Ranjit N, Shea S, Cushman M. Association of optimism and pessimism with inflammation and hemostasis in the Multi-Ethnic Study of Atherosclerosis (MESA). Psychosom Med 2010;72(2):134-140 
96 Jain S, Mills PJ, von Känel R, Hong S, Dimsdale JE. Effects of perceived stress and uplifts on inflammation and coagulability. Psychophysiology 2007;44(1):154-160

97 Steptoe A, Demakakos P, de Oliveira C, Wardle J. Distinctive biological correlates of positive psychological well-being in older men and women. Psychosom Med 2012;74(5):501-508

98 von Känel R, Kudielka BM, Abd-el-Razik A, Gander ML, Frey K, Fischer JE. Relationship between overnight neuroendocrine activity and morning haemostasis in working men. Clin Sci (Lond) 2004;107(1):89-95

99 von Känel R, Mausbach BT, Kudielka BM, Orth-Gomér K. Relation of morning serum cortisol to prothrombotic activity in women with stable coronary artery disease. J Thromb Thrombolysis 2008;25(2):165-172

100 Lippi G, Franchini M, Salvagno GL, Montagnana M, Guidi GC. Higher morning serum cortisol level predicts increased fibrinogen but not shortened APTT. J Thromb Thrombolysis 2008;26(2): 103-105

101 von Känel R, Nelesen RA, Ziegler MG, Mausbach BT, Mills PJ, Dimsdale JE. Relation of autonomic activity to plasminogen activator inhibitor-1 plasma concentration and the role of body mass index. Blood Coagul Fibrinolysis 2007;18(4):353-359

102 von Känel R, Orth-Gomér K. Autonomic function and prothrombotic activity in women after an acute coronary event. J Womens Health (Larchmt) 2008;17(8):1331-1337

103 Isingrini E, Belzung C, d'Audiffret A, Camus V. Early and late-onset effect of chronic stress on vascular function in mice: a possible model of the impact of depression on vascular disease in aging. Am J Geriatr Psychiatry 2011;19(4):335-346

104 Yamamoto K, Takeshita K, Shimokawa T, et al. Plasminogen activator inhibitor-1 is a major stress-regulated gene: implications for stress-induced thrombosis in aged individuals. Proc Natl Acad Sci U S A 2002;99(2):890-895

105 Venugopal B, Sharon R, Abramovitz R, Khasin A, Miskin R. Plasminogen activator inhibitor-1 in cardiovascular cells: rapid induction after injecting mice with kainate or adrenergic agents. Cardiovasc Res 2001;49(2):476-483

106 von Känel R, Thayer JF, Fischer JE. Nighttime vagal cardiac control and plasma fibrinogen levels in a population of working men and women. Ann Noninvasive Electrocardiol 2009;14(2):176-184

107 Hänsel A, Hong S, Cámara RJ, von Känel R. Inflammation as a psychophysiological biomarker in chronic psychosocial stress. Neurosci Biobehav Rev 2010;35(1):115-121

108 von Känel R, Nelesen RA, Mills PJ, Ziegler MG, Dimsdale JE. Relationship between heart rate variability, interleukin-6, and soluble tissue factor in healthy subjects. Brain Behav Immun 2008;22(4):461-468

109 von Känel R, Kudielka BM, Helfricht S, et al. The effects of aspirin and nonselective beta blockade on the acute prothrombotic response to psychosocial stress in apparently healthy subjects. J Cardiovasc Pharmacol 2008;51(3):231-238

110 von Känel R, Kudielka BM, Helfricht S, et al. Effects of aspirin and propranolol on the acute psychological stress response in factor VIII coagulant activity: a randomized, double-blind, placebocontrolled experimental study. Blood Coagul Fibrinolysis 2008; 19(1):75-81

111 Tomoda F, Takata M, Kagitani S, et al. Effects of a novel calcium antagonist, benidipine hydrochloride, on platelet responsiveness to mental stress in patients with essential hypertension. J Cardiovasc Pharmacol 1999;34(2):248-253

112 Gebara OC, Jimenez AH, McKenna C, et al. Stress-induced hemodynamic and hemostatic changes in patients with systemic hypertension: effect of verapamil. Clin Cardiol 1996;19(3): 205-211

113 Wirtz PH, Bärtschi C, Spillmann M, Ehlert U, von Känel R. Effect of oral melatonin on the procoagulant response to acute psychosocial stress in healthy men: a randomized placebo-controlled study. J Pineal Res 2008;44(4):358-365

114 Ekholm M, Wallén NH, Johnsson H, Eliasson K, Kahan T. Longterm angiotensin-converting enzyme inhibition with ramipril reduces thrombin generation in human hypertension. Clin Sci (Lond) 2002;103(2):151-155

115 Bröijersén A, Eriksson M, Leijd B, Angelin B, Hjemdahl P. No influence of simvastatin treatment on platelet function in vivo in patients with hypercholesterolemia. Arterioscler Thromb Vasc Biol 1997;17(2):273-278

116 Bröijersén A, Eriksson M, Angelin B, Hjemdahl P. Gemfibrozil enhances platelet activity in patients with combined hyperlipoproteinemia. Arterioscler Thromb Vasc Biol 1995;15(1):121-127

117 Serebruany VL, Glassman AH, Malinin AI, et al; Sertraline AntiDepressant Heart Attack Randomized Trial Study Group. Platelet/ endothelial biomarkers in depressed patients treated with the selective serotonin reuptake inhibitor sertraline after acute coronary events: the Sertraline AntiDepressant Heart Attack Randomized Trial (SADHART) Platelet Substudy. Circulation 2003; 108(8):939-944

118 van Zyl LT, Lespérance F, Frasure-Smith N, et al. Platelet and endothelial activity in comorbid major depression and coronary artery disease patients treated with citalopram: the Canadian Cardiac Randomized Evaluation of Antidepressant and Psychotherapy Efficacy Trial (CREATE) biomarker sub-study. J Thromb Thrombolysis 2009;27(1):48-56

119 Morel-Kopp MC, McLean L, Chen Q et al. The association of depression with platelet activation: evidence for a treatment effect. J Thromb Haemost 2009;7(4):573-581

120 Geiser F, Gessler K, Conrad R, Imbierowicz K, Albus C, Harbrecht U. Can activation of coagulation and impairment of fibrinolysis in patients with anxiety and depression be reversed after improvement of psychiatric symptoms? Results of a pilot study. J Nerv Ment Dis 2012;200(8):721-723

121 Claesson M, Birgander LS, Jansson JH, et al. Cognitive-behavioural stress management does not improve biological cardiovascular risk indicators in women with ischaemic heart disease: a randomized-controlled trial. J Intern Med 2006;260(4):320-331

122 Vlachopoulos C, Xaplanteris P, Alexopoulos N, et al. Divergent effects of laughter and mental stress on arterial stiffness and central hemodynamics. Psychosom Med 2009;71(4):446-453

123 Blombäck M, Konkle BA, Manco-Johnson MJ, Bremme K, Hellgren M, Kaaja R; ISTH SSC Subcommittee on Women's Health Issues. Preanalytical conditions that affect coagulation testing, including hormonal status and therapy. J Thromb Haemost 2007;5(4): 855-858

124 Tofler GH, Muller JE. Triggering of acute cardiovascular disease and potential preventive strategies. Circulation 2006;114(17): $1863-1872$ 